\title{
Article \\ Evaluating Soil Carbon as a Proxy for Erosion Risk in the Spatio-Temporal Complex Hydropower Catchment in Upper Pangani, Northern Tanzania
}

\author{
Aloyce I. M. Amasi ${ }^{1, *(\mathbb{D}}$, Maarten Wynants ${ }^{2} \mathbb{D}$, Remigius A. Kawala ${ }^{3} \mathbb{D}$, Shovi F. Sawe ${ }^{3}$, William H. Blake ${ }^{2}$ \\ and Kelvin M. Mtei ${ }^{1}(\mathbb{D}$ \\ 1 School of Material, Energy, Water and Environmental Science, The Nelson Mandela African Institution of \\ Science and Technology, P.O. Box 447, Arusha 23311, Tanzania; kelvin.mtei@nm-aist.ac.tz \\ 2 School of Geography, Earth and Environmental Sciences, University of Plymouth, Drake Circus Plymouth, \\ Devon PL4 8AA, UK; maarten.wynants@plymouth.ac.uk (M.W.); william.blake@plymouth.ac.uk (W.H.B.) \\ 3 Department of Research and Development, Tanzania Atomic Energy Commission, P.O. Box 743, \\ Arusha 23114, Tanzania; remegius.kawalla@taec.go.tz (R.A.K.); shomvi.sawe@taec.go.tz (S.F.S.) \\ * Correspondence: aamasi@nm-aist.ac.tz; Tel.: +255-7-6687-7920
}

\section{check for} updates

Citation: Amasi, A.I.M.; Wynants, M.; Kawala, R.A.; Sawe, S.F.; Blake, W.H.; Mtei, K.M. Evaluating Soil Carbon as a Proxy for Erosion Risk in the Spatio-Temporal Complex Hydropower Catchment in Upper Pangani, Northern Tanzania. Earth 2021, 2, 764-780. https://doi.org/ 10.3390 /earth2040045

Academic Editor:

Christian Conoscenti

Received: 8 September 2021

Accepted: 12 October 2021

Published: 15 October 2021

Publisher's Note: MDPI stays neutral with regard to jurisdictional claims in published maps and institutional affiliations.

Copyright: (c) 2021 by the authors. Licensee MDPI, Basel, Switzerland. This article is an open access article distributed under the terms and conditions of the Creative Commons Attribution (CC BY) license (https:// creativecommons.org/licenses/by/ $4.0 /)$.
Abstract: Land use conversion is generally accompanied by large changes in soil organic carbon (SOC). SOC influences soil erodibility through its broad control on aggregate stability, soil structure and infiltration capacity. However, soil erodibility is also influenced by soil properties, clay mineralogy and other human activities. This study aimed to evaluate soil organic carbon as proxy of soil erosion risk in the Nyumba ya Mungu (NYM) catchment in Northern Tanzania. Soil organic carbon (SOC) was measured by an AgroCares scanner from which the soil organic matter (SOM) was derived using the conversional van Bemmelen factor of 1.72. A regression analysis performed between the measured loss on ignition (LOI) values and SOM from the AgroScanner showed a strong positive correlation in all land use classes $\left(\mathrm{LOI}_{\mathrm{FL}} \mathrm{R}^{2}=0.85, \mathrm{r}=0.93, p<0.0001\right.$; $\mathrm{LOI}_{\mathrm{CL}} \mathrm{R}^{2}=0.86, \mathrm{r}=0.93$, $p=0.0001 ; \mathrm{LOI}_{\mathrm{GL}} \mathrm{R}^{2}=0.68, \mathrm{r}=0.83, p=0.003 ; \mathrm{LOI}_{\mathrm{BS}} \mathrm{R}^{2}=0.88, \mathrm{r}=0.94, p=0.0001 ; \mathrm{LOI}_{\mathrm{BL}} \mathrm{R}^{2}=0.83$, $\mathrm{r}=0.91, p=0.0002)$. This indicates that SOC from the soil scanner provided a good representation of the actual SOM present in soils. The study also revealed significant differences in the soil aggregate stability (WSA) and SOM stock between the different land use types in the Upper Pangani Basin. The WSA decreases approximately in the following order: grassland > forest land > bare land > cultivated $>$ bush land. Land use change can thus potentially increase the susceptibility of soil to erosion risk when SOC is reduced. Since WSA was directly related to SOM, the study indicates that, where formal measurements are limited, this simple and inexpensive aggregate stability test can be used by farmers to monitor changes in their soils after management changes and to tentatively assess SOC and soil health.

Keywords: aggregate stability; soil organic matter; AgroScanner; loss on ignition; soil slake test

\section{Introduction}

The changing demographics in Tanzania have created an increasing demand for land, food and water, leading to changes in land and water use. While the land remains constant, the demand for food and water is expanding linearly while the population increase in Tanzania is growing exponentially, with an average growth rate of 3\% annually [1]. For instance, in 1950, Tanzania's population was 7.6 million people, growing to 61.5 million people in 2021 [1]. Deforestation and the loss of permanent vegetation through the fast expansion of agricultural land and growing urbanization with respect to population increase has accelerated soil loss rates and downstream siltation [2-5]. The mean rate of soil loss by water in Tanzania is 4.1 and $10.1 \mathrm{tha}^{-1} \mathrm{yr}^{-1}$ for all land cover classes and per cropland, respectively [6]. The sedimentation rate in the catchment's (the Nyumba ya Mungu) hydropower reservoir is averagely $1.5 \mathrm{~g} \mathrm{~cm}^{-2} \mathrm{yr}^{-1}$ [7]. Studies by Vanmaercke, Poesen, Broeck, 
and Nyssen [8] revealed that the sediment yield in East Africa typically range between 100 to $1000 \mathrm{t} / \mathrm{km}^{2}$ /year. The global watch forest also showed the deforestation rate in Tanzania whereby, from 2001 to 2020, Tanzania lost 2.7 Mha of tree cover, equivalent to a $10 \%$ decrease in tree cover since 2000, and $910 \mathrm{Mt}$ of $\mathrm{CO}_{2}$ emissions (www.globalforestwatch.org accessed on 7 September 2021). Unsustainable land use practices are the major cause of the degradation of Tanzania's agricultural soils. Soil degradation is activated by many physical, chemical, biological and ecological processes that lower the quality and potential productivity of the soil $[9,10]$. Increased rates of soil erosion remove both soil particles and associated nutrients from the land [11]. Unsustainable soil management is therefore a primary cause of the reduced agronomic productivity in Tanzania [12].

The stability of the soil aggregates is vital for a healthy soil structure and protection against erosion. Soil organic matter (SOC) plays a crucial role in the formation of stable aggregates. It stabilizes soil structure, improves the soil's physical properties and enhance nutrient recycling $[13,14]$. Soil aggregates are the building blocks of soil structure, and soil aggregate stability is therefore commonly used as an indicator of soil physical quality [13,15-17]. Aggregate stability is defined as the resistance of the aggregate soil breakdown against the external destructive effects of rainfall, runoff and wind. Generally, soils with a higher aggregate stability have higher resistance to erosion and a better water infiltration. Soil aggregate stability is dependent on multiple soil properties such as soil organic matter content and soil texture $[18,19]$. SOM supports aggregate stability through increasing the mechanical strength, increasing the cohesion within the aggregates and lowering the wettability $[20,21]$. SOM is influenced by natural factors, such as the changing of rainfall frequency and the input of plant residuals to the soil [22,23]. However, humans also influence SOM across a range of timeframes through the harvesting of the live and dead vegetation, cropping, applying manure or compost, plowing [24], deforestation [25] and afforestation [26]. Changes in SOM subsequently have substantial impacts on soil aggregate stability [24,26,27]. Different size fractions in soil aggregates also have different percentages of carbon present, which influences their stability and erodibility. Macroaggregates have less organic matter by mass, leading to a lower aggregate stability and a high erodibility factor thus becoming prone to erosion while the micro-aggregate is less susceptible to erosion [28]. The amount of carbon present in the size fractions of aggregates enables the determination of the amount of organic matter that can potentially be lost due to the erosion process, which adversely affects the structural condition of the soil [29].

There is currently still a lack of understanding on the dynamics and role of soil organic matter on soil erodibility in Tanzania's complex soil systems. Although erosion risk is controlled by many factors, there is a need for an evaluation of the erosion risk linked to soil quality, an approach that has widespread applicability in the resource-poor agropastoral communities of Tanzania. In this context, SOM seems promising due to its all-embracing influence on the physical, chemical and biological properties of soils [30], which makes it very sensitive to management, among other attributes. The aim of this study was to evaluate the soil carbon as a proxy for soil erosion risk in the Nyumba ya Mungu catchment. Moreover, the impacts of land use change on SOM and aggregate stability were assessed based on the influence on soil erodibility.

\section{Materials and Methods}

\subsection{Study Site}

The Upper Pangani Basin (UPB) in northern Tanzania includes the highlands of the Africa's highest peak, Mt. Kilimanjaro (5985 m), and fifth highest peak, Mt. Meru (4566 m). The catchment has a total land and water area of about $13,000 \mathrm{~km}^{2}$ [31], extending between the Latitudes $3^{\circ} 00^{\prime} 00^{\prime \prime}$ and $4^{\circ} 3^{\prime} 50^{\prime \prime}$ South, and the Longitudes $36^{\circ} 20^{\prime} 00^{\prime \prime}$ and $38^{\circ} 00^{\prime} 00^{\prime \prime}$ East. The area experiences a tropical climate with altitude effects on temperature and rainfall, with a long wet/rain season from March to May and a short rainy season from October to December [32,33]. In addition to seasonality, the climate is affected spatially through altitude effects on temperature and rainfall. The average rainfall in the lowlands (800 m.a.s.1) 
is $900 \mathrm{~mm}$ /year, and in the highlands (2200 m.a.s.l), it is $>2200 \mathrm{~mm} /$ year [34-37]. Catchment's geology is volcanic, comprising olivine and alkaline basalts, phonolites, trachytes, nephelinites and pyroclastics [37-39]. The major soil types in the watershed comprise Nitisols, Luvisols, Solonchaks, Chernozems, Leptosols and Histosols [40] (Figure 1). The Nitisols cover the highlands to the lowlands and are predominantly developed on volcanic material. They are usually deeply and well-drained and have a stable structure and a high clay and nutrient content. With proper management, they have medium to high potential for rain-fed agriculture. The Luvisols are mostly constrained to the lowlands of the catchment. They are highly weathered with a subsurface accumulation of clay and are characterized by low nutrient retention and a high susceptibility to surface crusting and erosion. However, with proper management, they have a medium agricultural potential. The Solonchaks are located in lowland depressions or salt pans and are characterized by high rates of evaporation of runoff water, leaving a high concentration of soluble salts. They have a limited potential for cultivation, only with salt tolerant crops. Most Solonchaks are therefore used for extensive grazing or as natural reserves. Histosols are acidic, organic soils that form when fallen plant material decomposes more slowly than it accumulates [41]. They are constrained to wetlands on the upper parts of Mount Kilimanjaro and Mount Meru, where they have formed under almost permanently saturated conditions. Chernozems are the dominant soil type in the Kikuletwa sub-catchment. They are fertile soils that are currently mostly used for agricultural production. These soils are characterized by a high degree of biological soil mixing and soil organic carbon, leading to the formation of biologically stabilized soil aggregates on the soil surface [42]. Leptosols are generally weak aggregated coarse or medium-textured soils with limited profile development, mostly located in the highlands and in the Kikuletwa sub-catchment. The soil erodibility factor of

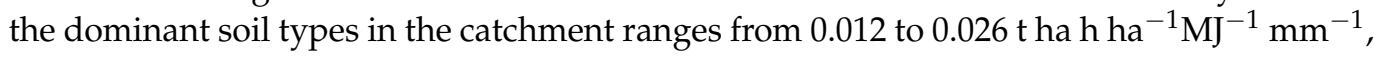
according to Fenta et al. [6], which suggests that the catchment has significant soil aggregate stability. The land cover in the catchment is mostly driven by the rainfall-elevation gradient ranging from permanently wet montane forests on the higher altitudes to savannah grassland on the lowlands [43]. The agricultural activities are mostly concentrated on the lower slopes between 900 and 1800 m.a.s.l, where the majority of the population established.

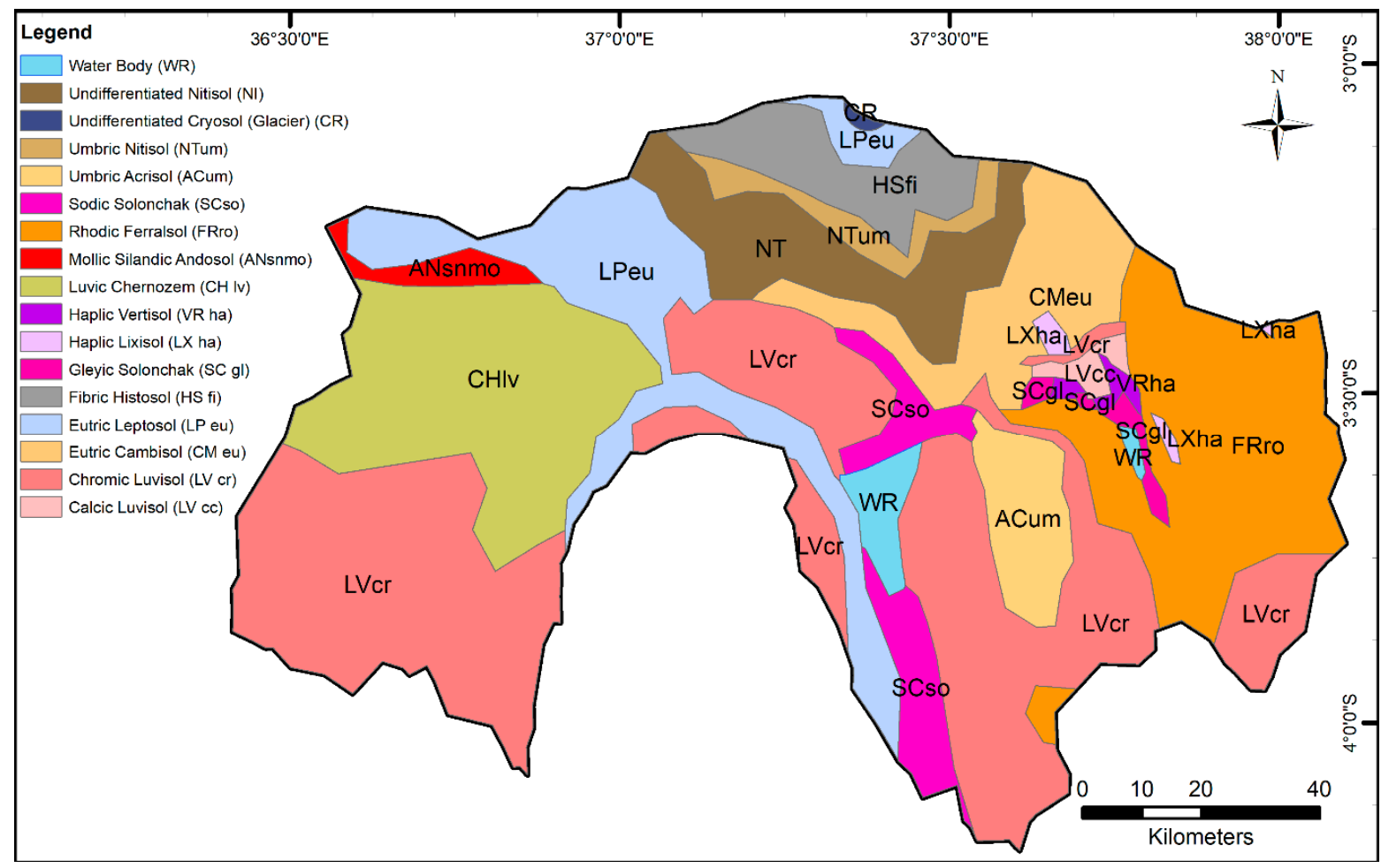

Figure 1. The map of the Upper Pangani Basin details the major soil types in the catchment [40]. 


\subsection{Data Acquisition for Land Use Classification}

Ortho-rectified and geometrically corrected Landsat images (Landsat 4-5 and Landsat 8) with a resolution of $30 \mathrm{~m}$ were obtained from the USGS Earth Explorer website (https: glovis.usgs.gov / accessed on 7 September 2021). For this specific study, Landsat images captured in February 1987 for Landsat 4-5 and 2017/18 for Landsat 8 were selected based on the lack of interfering cloud cover and ability to reconstruct land cover change over time. Before the analysis, the images were projected to UTM zone $37 \mathrm{~S}$ allowing spatial assessment in combination with other spatial data of the study area [44].

\subsection{Image Classification of Different Land Use Classes}

Geo-tagged photos and field notes were gathered during multiple ground-truthing campaigns to offer a comprehensive documentation of the land cover spectrum. By using these ground observations, complemented with Google Earth images, the major land cover types in the area were delineated into spectral signature files. The supervised classification by maximum likelihood algorithm method in ArchMap uses these signature files to extrapolate across the full Landsat image database into the pre-defined land cover classes. A visual examination and comparison with high resolution aerial imagery from Google Earth was used to remove potential incorrectly classified features. A raster calculator function was used to direct the correct elevation of a particular land use class based on the expert knowledge of the study area as explained by Taweesuk et al. [45]. The Expert classification is aimed at improving classification accuracy thus used to integrate remotesensed data with other sources of georeferenced information such as digital elevation model (DEM), land use data and spatial texture. A total of 9 major classes of land cover were classified, representing both changes due to natural drivers and human influence (Table 1).

Table 1. Land use/cover classes and their description.

\begin{tabular}{|c|c|c|}
\hline $\mathrm{S} / \mathrm{N}$ & Land Use/Cover Class & Description \\
\hline 1 & Agricultural land (CL) & All cultivated land with crops and harvested crops \\
\hline 2 & Water (WT) & $\begin{array}{l}\text { Including water in wetlands, rivers, irrigated areas and } \\
\text { fish ponds }\end{array}$ \\
\hline 3 & Grassland (GL) & $\begin{array}{l}\text { Areas dominated by short and tall grasses and bare soils in the } \\
\text { dry season. }\end{array}$ \\
\hline 4 & Bush land (BS) & Areas dominated with shrubs and less closed canopy \\
\hline 5 & Bare land (BL) & Areas includes gullies, bare soils, rocky, sand and quarry \\
\hline 6 & Built-up area (BLA) & $\begin{array}{c}\text { Man-made infrastructure (urban and rural settlements) and } \\
\text { roads (tarmac or paved) }\end{array}$ \\
\hline 7 & Forest (FL) & $\begin{array}{c}\text { Includes natural and planted forests with closed trees and } \\
\text { closed canopy }\end{array}$ \\
\hline 8 & Wetland (WTL) & $\begin{array}{c}\text { Areas moderately saturated with water seasonally } \\
\text { or permanently }\end{array}$ \\
\hline 9 & Glacier ice (GLA) & Includes areas enclosed with glacier and ice \\
\hline
\end{tabular}

\subsection{Soil Scanning to Estimate Soil Organic Matter}

An AgroCares scanner, a portable handheld Near Infrared (NIR) sensor for soil scanning [46], was used to scan the soil samples to evaluate SOC content. The scanner is connected to an app ("soil cares app" downloaded from Google Play/Apple store) using a smartphone via Bluetooth. A spectral analysis of the scanned soil is sent to the application on the smartphone via Bluetooth. Subsequently, the smartphone application connects to AgroCares's global calibration database to convert the spectral image into the required soil data.

A hand trowel and scoop were used to collect a soil sample between $0-5 \mathrm{~cm}$ depth, which was put in a bucket and well mixed. The samples were clearly labelled, and the coordinates of the sampling location were recorded using an Infinix Hot 9 Android 10 XOS 6.0. The scanner was calibrated in situ following manufacturer instructions. The scanner 
was placed on the sub-samples (drawn from the bucket) on the sample tray, and per soil sample, the scanner performed 5 scans. Using the reflectance signature and global calibrated database, the application estimated the following soil parameters: soil organic carbon $(\mathrm{g} / \mathrm{kg}), \mathrm{pH}$, soil texture class, total Phosphorus $(\mathrm{g} / \mathrm{kg})$, Potassium $(\mathrm{mmol}+/ \mathrm{kg})$, soil temperature $(\circ \mathrm{C})$ and Cation exchange capacity $(\mathrm{mmol}+/ \mathrm{kg})$. The SOM was derived from the estimated SOC using the conversional van Bemmelen factor of $1.72[47,48]$. The conversion factor is based on the assumption that the organic matter is $58 \%$ carbon [49].

\subsection{Loss on Ignition to Estimate Soil Organic Matter}

Loss-on-ignition was determined on the oven-dried subsamples of soil fractions. Approximately $20 \mathrm{~g}$ of air-dry soil was added to previously ignited and weighed porcelain crucibles, dried at $105^{\circ} \mathrm{C}$ for $12 \mathrm{~h}$ in a ventilated oven, cooled in a desiccator and weighed again. Finally, the crucibles were ignited at $550{ }^{\circ} \mathrm{C}$ for $4 \mathrm{~h}$ in a muffle furnace (Cole-Parmer ${ }^{\circledR}$ StableTemp). After ignition, the crucibles were cooled in a desiccator and weighed. The LOI was calculated as the difference between the oven-dry weight (DW) before and after ignition and related to oven-dry soil, as shown in Equation (1):

$$
L O I_{550}=\frac{D W_{105}-D W_{550}}{D W_{105}} \times 100
$$

The values of the SOM obtained in percentages were compared with the SOM derived from the loss on ignition.

\subsection{Soil Aggregate Stability (Slake Test)}

Soil aggregate stability in water was assessed using a semi-quantitative method adapted from the USDA-ARS Soil Slake test method [50], wherein a value was assigned to the assessed soil samples based on the stability of soil aggregates in water (WSA). Soil sample aggregates with a diameter of approximately $10 \mathrm{~mm}$ were collected using a trowel from different land use types and subsequently air-dried at room temperature. The air-dried aggregates were placed on a 6-mm mesh that was fixed on a basket cup. The basket cup with soil aggregates was subsequently immersed with water on top of the mesh. Following the behavioral criteria of the aggregates in water, (Table 2), the slaking away of the soil fragments was recorded for five minutes. For each soil sample, a soil stability score was rated according to the time required for $50 \%$ of the soil aggregates and the proportion of the soil fragments remaining on the mesh after the five minutes of immersion.

Table 2. Criteria for scoring soil stability in water adapted from Herrick et al. [50].

\begin{tabular}{cc}
\hline Stability Class & Criteria for Assignment to Stability Class (for "Standard Characterization") \\
\hline 0 & $\begin{array}{c}\text { Soil too unstable to sample (falls through sieve). } \\
1\end{array}$ \\
2 & $\begin{array}{c}50 \% \text { of structural integrity lost within } 5 \mathrm{~s} \text { of insertion AND or }<10 \% \text { remains } \\
\text { after agitation }\end{array}$ \\
3 & $\begin{array}{c}50 \% \text { of structural integrity lost } 30-300 \mathrm{~s} \text { after insertion AND or }<10 \% \text { remains } \\
\text { after agitation }\end{array}$ \\
4 & $10-25 \%$ of soil remains after 5 min agitation \\
5 & $25-50 \%$ of soil remains after 5 min agitation \\
7 & $50-75 \%$ of soil remains after 5 min agitation \\
8 & $75-90 \%$ of soil remains after 5 min agitation \\
& $>90 \%$ of soil remains after 5 min agitation \\
\hline
\end{tabular}

\subsection{Statistical Analysis}

Initially, a regression analysis was conducted to determine the correlation between SOM content \% derived from the scanner and SOM content \% derived from the LOI experiments. Data were subsequently tested for normality, where, for the WSA, only values 
for forest land and cultivated land were normally distributed $(p<0.0005$ and $p<0.018$, respectively). For LOI, only forestland and bush land were also normally distributed ( $p<0.036$ and $p<0.008$, respectively) and normally undistributed to the rest of land uses, while for SOM, only bush land data were normally distributed. Following these results, the non-parametric Kruskal-Wallis test was carried out in SPSS (Statistical Package for Social Science) to test if there were significant differences in the measured LOI, scanned SOM and estimated WSA between the different land use types. The differences were subsequently visualized using boxplots allowing a comparison of the mean values and variability of LOI, SOM and WSA within and between land use sites.

\section{Results and Discussion}

\subsection{Land Use/Cover Changes}

A visual and numerical representation of the land cover changes are summarized in (Figure 2) and in (Table 3), respectively. The summary provides the information on the specific land cover types that has been converted to others and those that have been resistant to change. The net decrease in forest, bare land, grassland and bush land are clear distinguishing trends that evidence their conversion to mostly agriculture land by $34.6 \%\left(4542 \mathrm{~km}^{2}\right)$. Built-up areas were observed to have significantly increased by $6.17 \%$ $\left(809.9 \mathrm{~km}^{2}\right)$. This corresponds to previous studies that observed high levels of deforestation and the loss of permanent vegetation through the fast expansion of agricultural land and growing urbanization [2-5,51]. The local manifestation of urbanization includes the establishment of the Siha district and the emergence of many villages and urban suburbs along roads across the catchment [52,53]. The expansion of agricultural land and settlements has also led to the disappearance of riparian forests and the degradation of riverbanks in the lowlands [2]. Another pronounced change is the considerable net decrease in wetlands by $-3.96 \%\left(519.8 \mathrm{~km}^{2}\right)$ that would have been caused by drainage and potentially climatic change and variability. The conversion of the catchment land cover types, for instance, the montane forests on mountain slopes, grassland and bush land to small- and large-scale plantations in the lowlands, is evidence of increased land use pressures $[54,55]$ and response to climate change impacts [56]. Another notable change evidenced by the literature is the decrease in the glaciers in the volcanic peaks of Mt. Kilimanjaro, which is an important indicator of environmental changes in the region [57,58]. Although the decrease in glaciers corresponds with the previous studies, the cloud cover in the top of the mountain may have influenced the classified image interpretation from which the spectral signatures from the Landsat images obscure the parts of the glacier, thus affecting the training samples as a result and impacting the absolute classification accuracy [59].

Table 3. Losses/gains in land use/cover areas.

\begin{tabular}{cccccc}
\hline \multirow{2}{*}{ LU Classes } & \multicolumn{2}{c}{$\mathbf{1 9 8 7}$} & \multicolumn{2}{c}{$\mathbf{2 0 1 8}$} & 1987-2018 \\
\cline { 2 - 6 } & Area $\mathbf{( k m}^{\mathbf{2}} \mathbf{~}$ & \% of Total & Area $\mathbf{( k m}^{\mathbf{2}} \mathbf{)}$ & \% of Total & \% Change \\
\hline Built up & 2203.35 & 16.8 & 3015.1413 & 22.9 & 6.17 \\
Agricultural land & 644.587 & 4.9 & 5191.2486 & 39.5 & 34.6 \\
Forest & 3302.27 & 25.16 & 1576.431 & 12.01 & -13.15 \\
Water & 79.7715 & 0.61 & 106.7616 & 0.81 & 0.2 \\
Wetland & 562.757 & 4.29 & 42.7257 & 0.33 & -3.96 \\
Bush land & 2147.58 & 16.36 & 1009.1025 & 7.69 & -8.36 \\
Grassland & 224.251 & 1.71 & 9.4374 & 0.07 & -1.64 \\
Bare land & 3950.95 & 30.1 & 2167.5091 & 15.66 & -29.94 \\
Glacier & 10.5264 & 0.08 & 9.6413 & 0.92 & -0.012 \\
\hline
\end{tabular}

The historical land use land cover change in the catchment is confirmed by other previous studies, which include the conversion of shrub and grassland and light vegetation to cultivated land from 1987 to 2005 in the Kahe plains [60], increased forest degradation 
in the lowlands from 1606 ha to 5170 ha between 1973 and 2000 [61], the conversion of about $39.5 \%$ of bush land to agricultural land between 1973 and 2000 [34], the degradation of more than $41 \mathrm{~km}^{2}$ of the forest between 1952 and 1982 [62], the conversion of about $49.97 \mathrm{~km}^{2}$ of shrubs and bush land to agriculture and other uses from 1961 to 2000 in the Kirua Vunjo division [59] and increased cultivated land from 54\% (in 1973) to $63 \%$ in 2000 on the southern and eastern slopes [63].

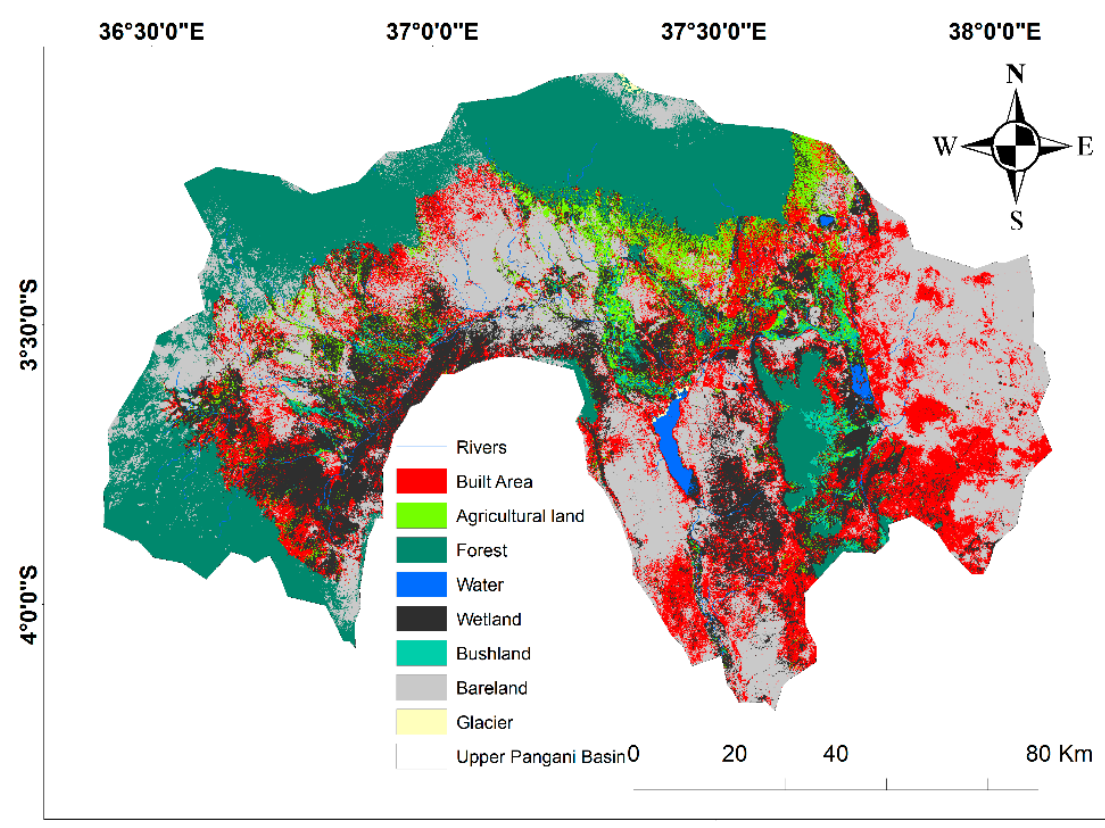

(a)

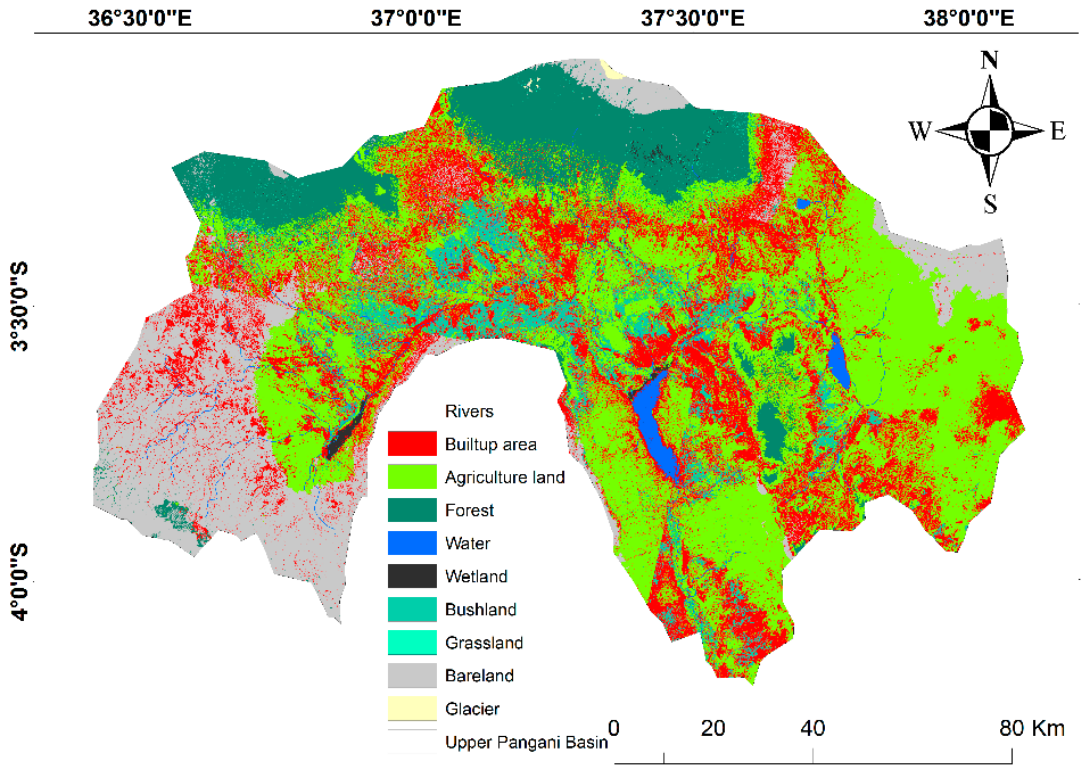

(b)

Figure 2. Land cover maps derived from Landsat imagery of (a) 1987 and (b) 2018, respectively detailing the changes in land use land cover from 1987 to 2018.

\subsection{Comparison of Scanner and Laboratory Estimates of SOM}

While SOM derived from the AgroCares scanner and converted using the van Bemmelen factor of 1.72 had higher values in all land types than those derived from LOI, a simple regression analysis between LOI and the estimated \% SOM from the AgroScanner showed 
a strong positive correlation ((a) $\mathrm{LOI}_{\mathrm{CU}} \mathrm{R}^{2}=0.86, \mathrm{r}=0.93, p=0.0001$; (b) $\mathrm{LOI}_{\mathrm{GL}} \mathrm{R}^{2}=0.68$, $\mathrm{r}=0.83, p=0.003 ;$ (c) $\mathrm{LOI}_{\mathrm{FL}} \mathrm{R}^{2}=0.85, \mathrm{r}=0.93, p=0.0001 ;$ (d) $\mathrm{LOI}_{\mathrm{BS}} \mathrm{R}^{2}=0.88, \mathrm{r}=0.94$, $p=0.0001$; (e) LOI $\mathrm{LL}^{2}=0.83, \mathrm{r}=0.91, p=0.0002$ ), Figure 3). From an environmental perspective, the LOI and SOM were significantly different between land uses, decreasing in the following order: bare land $>$ forest land $>$ bush land $>$ cultivated land $>$ grassland and bare land $>$ forest land $>$ grassland $>$ bush land $>$ cultivated land (Appendix A). However, the SOM for forest land and bare land were close at approximately $5 \%$ each, while the LOI for cultivated land and grassland were also similar at $2 \%$. Most soils in the catchment are characterized by a high clay content [64] that has the ability to contain more carbon $[65,66]$. Although the SOM stocks were significantly different among the land use systems, a similar pattern was observed between the forest land and bare land (Appendix A). This similar pattern might be explained by their dominating soil textures that were primarily loam to clay loam because these textures support the function of the soil biological community by providing a large and moist surface area in water films around loam and clay loam particles that are often protected within aggregates $[67,68]$. The strong relationship between the laboratory measured SOM (LOI) and SOM from the AgroCares scanner showed that LOI is a good method for the determinations of SOM where formal measurements are limited.

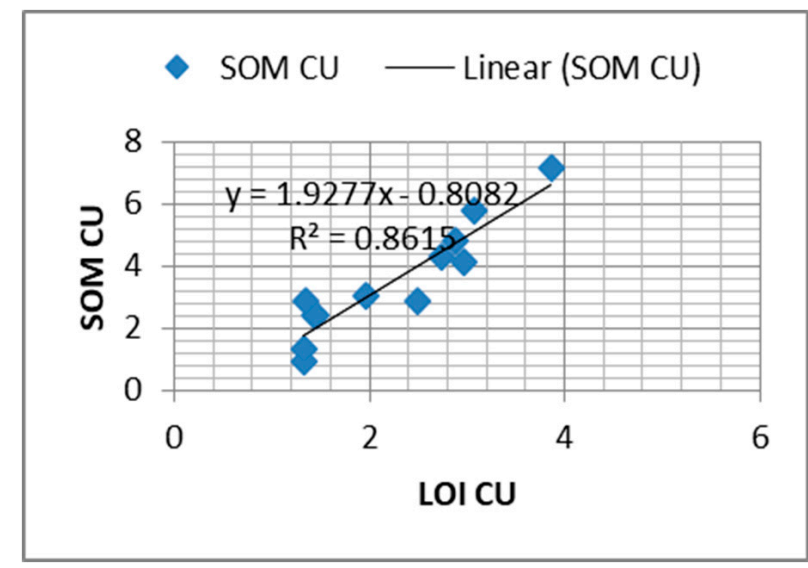

(a)

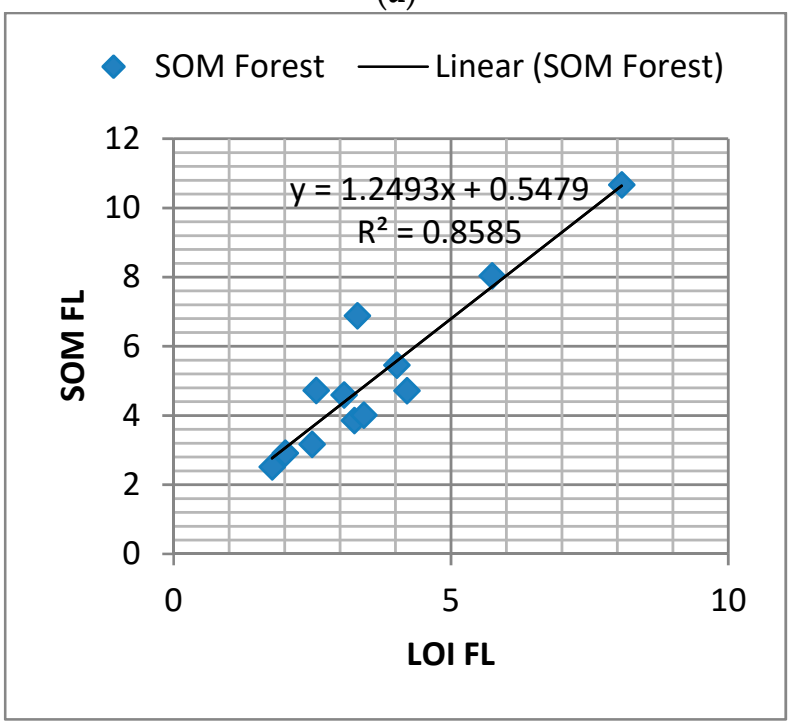

(c)

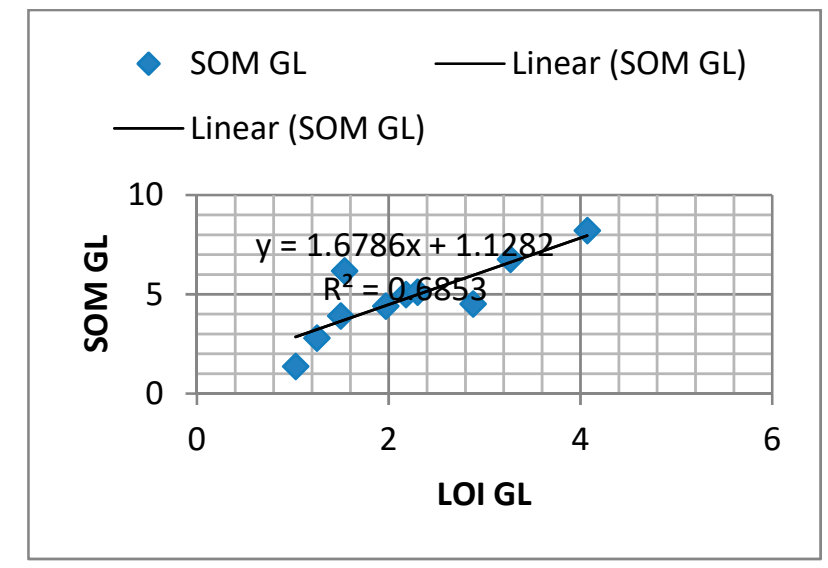

(b)

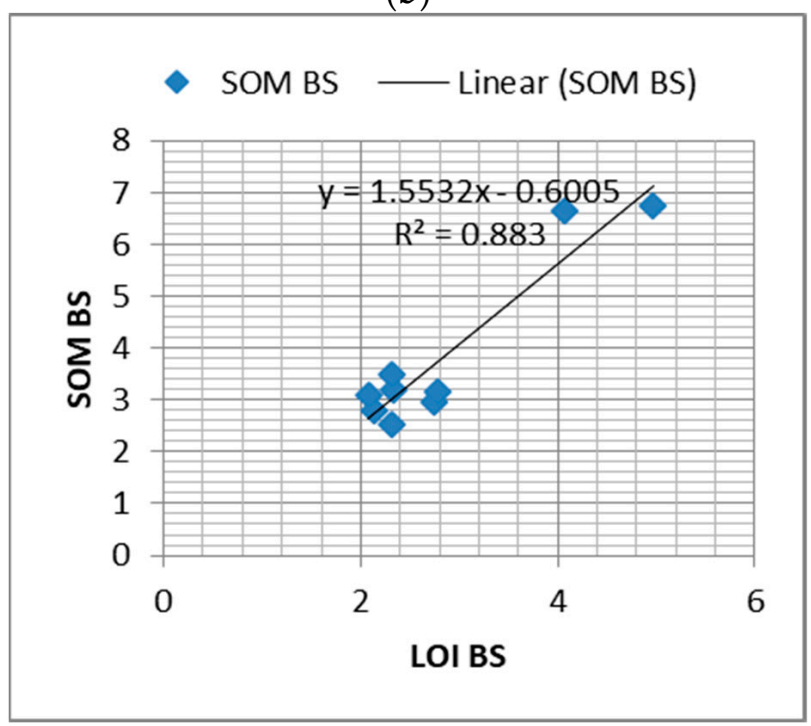

(d)

Figure 3. Cont. 


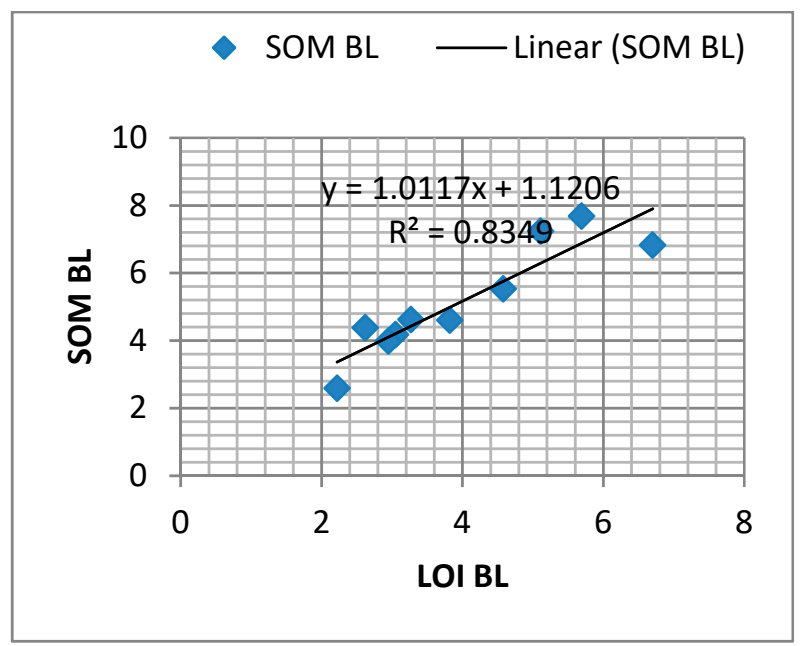

(e)

Figure 3. Relationship between loss on ignition (LOI) and soil organic matter (SOM) in different land use types (a) cultivated land (b) grassland (c) forest land (d) bush land and (e) bare land.

\subsection{Soil Organic Matter on Soil Aggregate Stability in Different Land Uses}

This study showed that there are significant differences in the soil aggregate stability and SOM stock between the different land use types in the Upper Pangani Basin. The soil aggregate stability decreases approximately in the following order: grassland $>$ forest land $>$ bare land $>$ cultivated land $>$ bush land (Appendix A). The results indicated that SOM and WSA were influenced by land management type (Figure 4). Similar to SOM stocks, the WSA in arable soils was typically less than in grassland, forestland and bare land. However, the significant difference between WSA in cultivated land in comparison to other land use types was observed with a wide range in WSA here indicating high variability in soil behavior under low SOM conditions. While the means of SOM in forest land and bare land were almost similar, there was a substantial difference in the median values of WSA, which might be attributed by difference in soil texture. Soil textures support the function of the soil biological community by providing a large and moist surface area in water films around loam and clay loam particles that are often protected within aggregates $[67,68]$. This similar pattern observed within and between land use types imply that the SOM and WSA were not only related to land management type (Figure 4 and Appendix A) but were also influenced by other factors such as soil textural properties, geology, clay content, exchangeable cations and other human activities. A multiple linear regression was run to evaluate the influence of SOM and LOI in aggregate stability (WSA) where all variables were statistically insignificantly to the prediction $p<0.05$ as follows: forestland (WSA, $R^{2}=0.235, p>0.05(0.299)$ ), cultivated land (WSA, $R^{2}=0.425, p>0.05$ (0.083)), grassland (WSA, $R^{2}=0.119, p>0.05(0.642)$ ), bare land (WSA, $R^{2}=0.161, p>0.05$ $(0.540)$ ), bush land (WSA, $\mathrm{R}^{2}=0.072, p>0.05(0.769)$ ). The results suggest that the SOM has influence on aggregate stability. The Kruskal-Wallis test also showed that the difference between the medians of LOI and SOM were not significantly different in all land uses across categories of WSA, $p>0.05$ (0.164 and 0.195), respectively, for bare land; $p>0.05$ (0.277 and 0.267), respectively, for bush land; $p>0.05$ (0.692 and 0.441), respectively, for grassland; $p>0.05$ (0.386 and 0.262), respectively, for cultivated land; and $p>0.05$ (0.127 and 0.197), respectively, for forestland (Figure 5), which implies that the aggregate stability is influenced by the SOM. The strong relationship between the LOI, SOM and WSA indicated that LOI approximation for WSA and the augmentation of organic matter in soil is a good strategy for farmers to reduce the risk of erosion. 


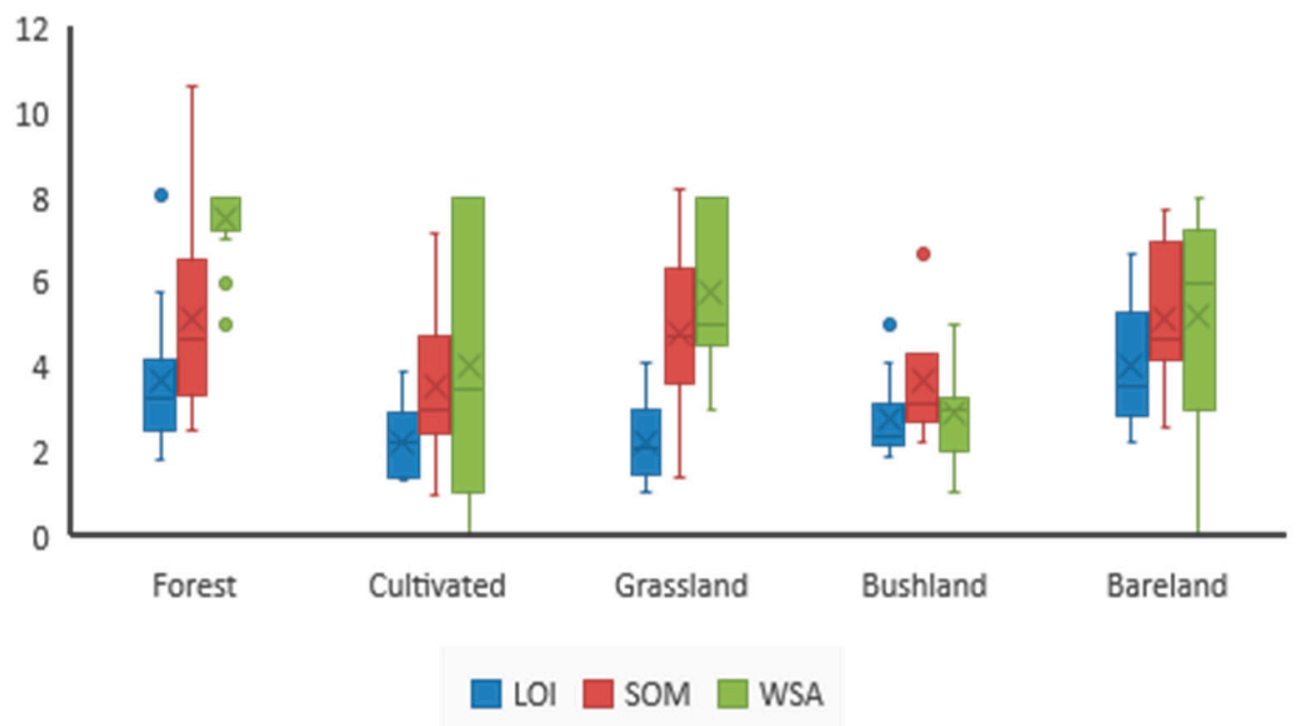

Figure 4. Boxplot comparing the ranges of LOI, SOM and WSA in each land use classification.

Hypothesis Test Summary

\begin{tabular}{|c|c|c|c|c|}
\hline & Null Hypothesis & Test & Sig. & Decision \\
\hline 1 & $\begin{array}{l}\text { The distribution of LOI is the same } \\
\text { across categories of WSA. }\end{array}$ & $\begin{array}{l}\text { Independent- } \\
\text { Samples } \\
\text { Kruskal- } \\
\text { Wallis Test }\end{array}$ & 0.163 & $\begin{array}{l}\text { Retain the } \\
\text { null } \\
\text { hypothesis. }\end{array}$ \\
\hline 2 & $\begin{array}{l}\text { The distribution of SOM is the same } \\
\text { across categories of WSA. }\end{array}$ & $\begin{array}{l}\text { Independent- } \\
\text { Samples } \\
\text { Kruskal- } \\
\text { Wallis Test }\end{array}$ & 0.067 & $\begin{array}{l}\text { Retain the } \\
\text { null } \\
\text { hypothesis. }\end{array}$ \\
\hline
\end{tabular}

Asymptotic significances are displayed. The significance level is 0.05 .

Figure 5. Kruskal-Wallis test results from SPSS.

The higher values of WSA in forest land and grassland indicate the stability of their soil structures in relation to longer-term vegetation cover. The forest soil exhibited the highest degree of the aggregate stability, which may be due to the higher SOM content input to soil vegetation cover, higher biological activity, and the protection of soils against degradative processes. The WSA was also high in the grasslands, which might be due to higher root biomass and the return of residuals to the soil. High root biomass and residues increase the organic matter content as the carbon source that support the water holding capacity in soil in turn becomes a conducive environment for the decomposition of organic matter [69]. The high WSA and SOM in bare land was unexpected and might be an influence on the high clay content, i.e., independent of land cover. Soil aggregate stability is affected by various parameters that act as binding agents, includes organic matter, soil texture, iron and aluminum oxides, carbonates and metal cations [70]. Increasing organic matter content enhances the stability of soil aggregates, and this is more distinct in soils with higher clay-fraction contents. The soil texture in the bare land was mostly clay loam and sandy clay loam, which have characteristics to immobilize different macro- and micronutrients and accelerate changes in the microbiological activity of the soil [17] (Appendix A). The low WSA and SOM content in cropland is typically an indication of tillage practices that reduce the soil aggregation process and aggravate soil loss through erosion. The weakening in the structural stability of cultivated soils may apparently be attributed to aggregate disruption and SOC distribution in various physical fractions, including tillage operations and other erosion-facilitating practices that lead to rapid breakdown $[13,71]$. The results 
of this study indicated that the cultivated lands have a lower SOM content compared to the natural land cover types. These results are in line with other studies elsewhere, indicating that cultivation usually markedly decreases soil carbon [67-69,72-74]. The forest conversion to cultivation land and settlement (Table 3) likely influences the level of organic carbon due to soil loss, and the more rapid oxidation process of SOC leads to rapid reductions in the SOM values of surface soils [75]. During cultivation, SOM can be lost through multiple processes such as tillage, increased erosion, reduction of vegetative input and biological activity. Therefore, the lower SOM in the catchment is evidence of the increasing conversion of land cover types to large scale plantations in the lowlands that may have influenced the hillslope erosion. In particular, the removal of plant residue from the soil surface layer through different land management practices, including cultivation, destroys soil macro-aggregate formation, which significantly alters soil texture and SOM and eventually increase soil erodibility. However, some crop land soils in the Msitu wa Tembo and Soko scheme had higher SOM and aggregate stability (Appendix A). This might be due to higher fertilizer input in cropland, which was revealed during the sampling campaign. The application of NPK fertilizer in the fields could have increased biological activity that promotes the formation of water-stable aggregates, which in turn improved the mechanical stability of soil aggregates by binding soil mineral particles [76]. The labile organic carbon (LOC) of SOM is responsible for organic amendments that enhance the water-stable aggregation process. In turn, the water-stable aggregation increases the availability of organic compounds that promote soil microorganism growth, which produces more extracellular polysaccharides and promotes aggregate formation [77]. The low WSA and SOM in bush land might be due to low root biomass production influenced by regular animal grazing that led to soil degradation. The present study and other studies by Nath and Lal. [78], Delelegn et al. [79] and Tang et al. [80] show that land use change has a major and important effect on soil aggregate stability, structure and, consequently, on water erosion.

The development of strategic land management plans based on the observed relationship between the slake test/aggregate stability and SOM is highly appropriate in soils with high clay contents because the distribution of clays in soil is associated with reduced infiltration and run-off, sediment load and crust formation [81]. Although the catchment soil sample were composed of large clay contents, substantial differences between the stability of aggregates in water was observed. From a sustainable land management perspective, soil organic carbon increases soil porosity and improves the mechanical flexibility to compression stress [82]. The cohesive effect of organic matter and its behavior to sustain soil microbial activities makes soil organic carbon content a good proxy for soil degradation [65]. The relationship between SOC content and the improved physical quality of soil, as well as the subsequent benefits for the quality of farmed soils, are widely acknowledged $[83,84]$.

\section{Conclusions}

The soil slake test method adapted from the USDA protocol was appropriately used to separate aggregates from different land use management types. The WSA scores were directly related to SOM and land use management types, signifying that the stability of aggregates in water could be used as a simple method by agronomists to assess soil erosion risk and to monitor soil health following land use management changes. The results presented in this paper revealed that land use/cover changes through anthropogenic activities have direct impact on the SOM and on the WSA. Unsustainable land use change exposes the land to water erosion and subsequently influences the soil organic carbon pool and significantly affects the quality and composition of soil organic matter and its migration. Following land use change, the quality and quantity of the SOC pools are affected and, consequently, the particles of the soil aggregate distribution and stability of the aggregates are influenced. This study recommends the sustainable land use management practices including afforestation, revegetation, sustainable grazing management programs and agricultural practices that emphasize soil conservation tillage systems and crop management 
to conserve the soil organic carbon that will eventually support the aggregate stability and decrease the risk of erosion. The potential to use the slake test is due to its wide applicability for many years to specific conditions of the soils that were tested and adapted. The slake test scoring protocols seemed to reasonably increase the sensitivity of the test without compromising the feasibility of its application by land managers than the existing USDA version. The robust associations between the WSA, SOM and land management practices in this study suggest that, where soil and climate conditions are similar within a defined region, the rapid assessment of the WSA using this approach offers an inexpensive means of assessing and providing a numerical score of 'soil health' and is a potential proxy for the direct measurement of SOC, which in turn is used to detect changes imposed by management. The prospect of using WSA as a rapid proxy for SOC change by agronomists where advanced measurements are limited would offer agronomists with a new tool for monitoring soil health. More research is essential to initiate its potential in different soil types in a range of management scenarios.

Author Contributions: Conceptualization, A.I.M.A., M.W., K.M.M. and W.H.B.; data curation, A.I.M.A., M.W., K.M.M. and W.H.B.; formal analysis, A.I.M.A. and W.H.B., investigation, A.I.M.A.; methodology, A.I.M.A., M.W., K.M.M. and W.H.B.; project administration, R.A.K. and S.F.S.; resources, R.A.K. and S.F.S., software, M.W., supervision, M.W., K.M.M. and W.H.B., validation, A.I.M.A., M.W., S.F.S. and W.H.B., writing—original draft, A.I.M.A., writing—review and editing, M.W. and W.H.B. All authors have read and agreed to the published version of the manuscript.

Funding: This research was funded by the Center for Water Infrastructure and Sustainable Energy Futures (WISE-Futures), grant number ACE (II). However, the project does not cover the cost of APCs.

Institutional Review Board Statement: Not applicable.

Informed Consent Statement: Not applicable.

Data Availability Statement: The data used to support the findings of this study are included in this article and in the Appendix A.

Conflicts of Interest: The authors declare that there are no conflicts of interest.

\section{Appendix A}

Table A1. LOI: SOM and WSA from different LU classes.

\begin{tabular}{cccccccc}
\hline \multicolumn{1}{c}{ Place } & \multicolumn{1}{c}{ Forest Land } & & & \\
\hline S/N & Coordinates (Latitude, Longitude) & Soil Texture & LOI & SOM & WSA \\
\hline 1 & Msitu wa Mbogo & -3.52608 & 36.87787 & Clay loam & 2.01 & 2.9 & 5 \\
\hline 2 & Mbuguni B/Kubwa & -3.56427 & 36.9433 & Loam & 3.073 & 4.59 & 8 \\
\hline 3 & Mawalla TPC & -3.50929 & 37.43439 & Clay loam & 1.77 & 2.5 & 7 \\
\hline 4 & Kifaru H School & -3.52821 & 37.55433 & Clay loam & 8.077 & 10.66 & 8 \\
\hline 5 & Kochakindo Kahe M & -3.50574 & 37.52873 & Clay loam & 5.74 & 8.03 & 8 \\
\hline 6 & Kikuletwa Bridge & -3.54595 & 37.31344 & Silty loam & 3.26 & 3.85 & 8 \\
\hline 7 & Sakilla Meru 1 & -3.33825 & 36.96451 & Loam & 4.2 & 4.7 & 8 \\
\hline 8 & Sakilla Meru 2 & -3.33333 & 36.96379 & Clay loam & 3.43 & 4.01 & 8 \\
\hline 9 & TPC Msarakia & -3.50892 & 37.34286 & Clay loam & 3.31 & 6.88 & 8 \\
\hline 10 & Sakilla Meru 3 & -3.33056 & 36.95861 & Loam & 4.02 & 5.45 & 8 \\
\hline 11 & Sakilla Meru 4 & -3.33958 & 36.96833 & Clay loam & 2.57 & 4.72 & 6 \\
\hline 12 & Bwawani & -3.54067 & 36.85773 & Clay loam & 2.496 & 3.16 & 8 \\
\hline & & Average & & & 3.66 & 5.12 & 5.5 \\
\hline
\end{tabular}


Table A1. Cont.

\begin{tabular}{|c|c|c|c|c|c|c|c|}
\hline \multicolumn{8}{|c|}{ Forest Land } \\
\hline $\mathbf{S} / \mathbf{N}$ & Place & Coordinates & Longitude) & Soil Texture & LOI & SOM & WSA \\
\hline \multicolumn{8}{|c|}{ Cultivated } \\
\hline 1 & Soko Scheme & -3.47948 & 37.50149 & Clay loam & 1.44 & 2.39 & 8 \\
\hline 2 & Kikuletwa bridge & -3.55414 & 37.30683 & Silty loam & 1.46 & 2.43 & 7 \\
\hline 3 & Kituri Mwanga & -3.50029 & 37.55564 & Sandy Clay loam & 1.97 & 3.04 & 4 \\
\hline 4 & Longoi kwa sadala & -3.40601 & 37.26669 & Clay & 1.35 & 2.89 & 8 \\
\hline 5 & Machame Gabriella & -3.33576 & 37.23301 & Clay & 2.73 & 4.32 & 5 \\
\hline 6 & Kochakindo Kahe/Msh & -3.4979 & 37.53082 & Loam & 3.86 & 7.14 & 3 \\
\hline 7 & Mnadani Machame & -3.32695 & 37. 23079 & Clay & 2.49 & 2.86 & 1 \\
\hline 8 & Msitu wa Tembo & -3.57212 & 37.30344 & Clay loam & 2.88 & 4.82 & 8 \\
\hline 9 & Kituri Proper & -3.53708 & 37.53488 & Sandy Clay loam & 3.07 & 5.78 & 0 \\
\hline 10 & Hai Town & -3.3258 & 37.16489 & Clay & 2.96 & 4.15 & 1 \\
\hline 11 & Chekereni & -3.458273 & 37.541108 & Silty loam & 1.32 & 0.93 & 1 \\
\hline 12 & Kiomo Kahe/Msh & -3.48152 & 37.52188 & Loam & 1.33 & 1.32 & 1 \\
\hline \multicolumn{5}{|c|}{ Average } & 2.24 & 3.51 & 3.92 \\
\hline \multicolumn{8}{|c|}{ Grassland } \\
\hline 1 & Kochakindo Kahe M & -3.50184 & 37.53162 & Clay & 2.88 & 4.51 & 8 \\
\hline 2 & Kituri Proper & -3.53377 & 37.53155 & Loam & 3.27 & 6.76 & 3 \\
\hline 3 & Tindigani Masaini & -3.43491 & 37.12334 & Clay loam & 4.07 & 8.20 & 5 \\
\hline 4 & Kiomu Majengo & -3.49196 & 37.53977 & Loam & 1.03 & 1.36 & 5 \\
\hline 5 & Chemchem & -3.58688 & 37.33495 & Loam & 1.25 & 2.79 & 8 \\
\hline 6 & Arusha Airport & -3.36487 & 36.61352 & Loam & 2.18 & 4.98 & 8 \\
\hline 7 & USA Leganga & -3.37275 & 36.84336 & Clay loam & 1.5 & 3.90 & 8 \\
\hline 8 & Mikocheni Kirungu & -3.59006 & 37.40077 & Silty loam & 1.54 & 6.17 & 5 \\
\hline 9 & Kahe Mashariki & -3.51569 & 37.51675 & Loam & 1.97 & 4.40 & 3 \\
\hline 10 & Ngaramtoni juu & -3.33712 & 36.62212 & Loam & 2.3 & 5.11 & 5 \\
\hline \multicolumn{5}{|c|}{ Average } & 2.19 & 4.82 & 5.8 \\
\hline \multicolumn{8}{|c|}{ Bushland } \\
\hline 1 & Maweni Kikwe & -3.45577 & 36.83135 & Clay & 2.74 & 2.98 & 3 \\
\hline 2 & Kituri Proper & -3.5346 & 37.53488 & Loamy Sand & 2.13 & 2.79 & 3 \\
\hline 3 & Karangai USA & -3.4814 & 36.86903 & Loam & 2.32 & 2.51 & 5 \\
\hline 4 & Bwawani & -3.5486 & 36.85565 & Clay loam & 2.34 & 3.18 & 2 \\
\hline 5 & Soko village & -3.49737 & 37.48351 & Loam & 4.97 & 6.76 & 3 \\
\hline 6 & Mikocheni B & -3.59063 & 37.42077 & Sandy Loam & 2.32 & 3.49 & 3 \\
\hline 7 & Masama Rundugai & -3.42217 & 37.23557 & Clay loam & 2.79 & 3.15 & 3 \\
\hline 8 & Mawalla & -3.55303 & 37.42863 & Clay loam & 4.07 & 6.66 & 2 \\
\hline 9 & Msitu wa Tembo & -3.57212 & 37.30344 & Clay loam & 2.08 & 3.09 & 4 \\
\hline 10 & Chekereni Majengo & -3.47629 & 37.53977 & Silty loam & 1.89 & 2.22 & 1 \\
\hline \multicolumn{5}{|c|}{ Average } & 2.86 & 3.7 & 2.9 \\
\hline
\end{tabular}


Table A1. Cont.

\begin{tabular}{cccccccc}
\hline \multicolumn{1}{c}{ Forest Land } & & & \\
\hline S/N & Place & Coordinates (Latitude, Longitude) & Soil Texture & LOI & SOM & WSA \\
\hline & & & Bareland & & & \\
\hline 1 & Kia Kaloleni 1 & -3.4401 & 37.04131 & Clay loam & 3.27 & 4.63 & 3 \\
\hline 2 & Lengijave & -3.20137 & 36.62547 & Loam & 3.05 & 4.18 & 8 \\
\hline 3 & Kia njiapanda & -3.37544 & 37.0482 & Clay loam & 2.62 & 4.39 & 0 \\
\hline 4 & Leisinyai & -3.46666 & 37.05372 & Loam & 2.95 & 3.99 & 8 \\
\hline 5 & Mikocheni A & -3.59006 & 37.40077 & Silty loam & 2.22 & 2.59 & 3 \\
\hline 6 & Mererani & -3.45943 & 37.03773 & Clay loam & 3.82 & 4.61 & 5 \\
\hline 7 & Sanya Palestina & -3.339693 & 37.08968 & Clay loam & 5.11 & 7.24 & 6 \\
\hline 8 & Sanya roadtall & -3.35777 & 37.09375 & Sandy Clay loam & 6.7 & 6.83 & 6 \\
\hline 9 & Sanya Power st & -3.37396 & 37.06587 & Sandy Clay loam & 5.69 & 7.69 & 6 \\
\hline 10 & Kia kaloleni 2 & -3.43999 & 37.04177 & Clay loam & 4.58 & 5.54 & 7 \\
\hline & & Average & & & 4.00 & 5.2 & 5.2 \\
\hline
\end{tabular}

\section{References}

1. United Nations, Department of Economic and Social Affairs, Population Division. World Population Prospects; United Nations: New York, NY, USA, 2019.

2. Mbonile, M.; Misana, S.; Sokoni, C. Land Use Change Patterns and Root Causes on the Southern Slopes of Mountain Kilimanjaro, Tanzania; LUCID Working Paper; Lucid International Ltd.: Nairobi, Kenya, 2003.

3. National Bureau of Statistics, Tanzania. Population Estimates by Districts for the Year 2016 and 2017; Ministry of Finance: Dar es Salaam, Tanzania, 2018.

4. NBS. Population and Housing Census: Population Distribution by Administrative Areas; Ministry of Finance: Dar es Salaam, Tanzania, 2012.

5. Tadross, M.; Wolski, P. Climate change modelling for the Pangani Basin to support the IWRM planning process. In Pangani Basin Water Board, Moshi and IUCN Eastern and Southern Africa Regional Programme, Nairobi, Kenya; IUCN: Gland, Switzerland, 2010.

6. Fenta, A.A.; Tsunekawa, A.; Haregeweyn, N.; Poesen, J.; Tsubo, M.; Borrelli, P.; Panagos, P.; Vanmaercke, M.; Broeckx, J.; Yasuda, H.; et al. Land susceptibility to water and wind erosion risks in the East Africa region. Sci. Total. Environ. 2020, 703, 135016. [CrossRef]

7. Amasi, A.I.M.; Wynants, M.; Kawalla, R.A.; Sawe, S.; Munishi, L.; Blake, W.H.; Mtei, K.M. Reconstructing the changes in sedimentation and source provenance in East African hydropower reservoirs: A case study of Nyumba ya Mungu in Tanzania. Earth 2021, 2, 485-514. [CrossRef]

8. Vanmaercke, M.; Poesen, J.; Broeckx, J.; Nyssen, J. Sediment yield in Africa. Earth-Sci. Rev. 2014, 136, 350-368. [CrossRef]

9. Lal, R. Restoring soil quality to mitigate soil degradation. Sustainability 2015, 7, 5875-5895. [CrossRef]

10. Tefera, B.; Ayele, G.; Atnafe, Y.; Jabbar, M.A.; Dubale, P. Nature and Causes of Land Degradation in Oromiya Region, Ethiopia—A Review; ILRI: Nairobi, Kenya; Ethiopian Agricultural Research Organization: Addis Ababa, Ethiopia, 2002.

11. Mbagwu, J.S. Aggregate Stability and Soil Degradation in the Tropics. In Proceedings of the Conference Report on the Lecture Given at the College on Soil Physics, Trieste, Italy, 3-21 March 2003; pp. 246-252.

12. Obalum, S.; Chibuike, G.; Peth, S.; Ouyang, Y. Soil organic matter as sole indicator of soil degradation. Environ. Monit. Assess. 2017, 189, 176. [CrossRef]

13. Six, J.; Paustian, K.; Elliott, E.T.; Combrink, C. Soil structure and organic matter I. Distribution of aggregate-size classes and aggregate-associated carbon. Soil Sci. Soc. Am. J. 2000, 64, 681-689. [CrossRef]

14. Martens, D. Plant residue biochemistry regulates soil carbon cycling and carbon sequestration. Soil Biol. Biochem. 2000, 32, 361-369. [CrossRef]

15. Xie, H.; Li, J.; Zhang, B.; Wang, L.; Wang, J.; He, H.; Zhang, X. Long-term manure amendments reduced soil aggregate stability via redistribution of the glomalin-related soil protein in macroaggregates. Sci. Rep. 2015, 5, 14687. [CrossRef] [PubMed]

16. Angers, D.A. Changes in soil aggregation and organic carbon under corn and alfalfa. Soil Sci. Soc. Am. J. 1992, 56, 1244-1249. [CrossRef]

17. Xie, J.-Y.; Xu, M.-G.; Ciren, Q.; Yang, Y.; Zhang, S.-L.; Sun, B.-H.; Yang, X.-Y. Soil aggregation and aggregate associated organic carbon and total nitrogen under long-term contrasting soil management regimes in loess soil. J. Integr. Agric. 2015, 14, $2405-2416$. [CrossRef]

18. Tisdall, J.M.; Oades, J.M. Organic matter and water-stable aggregates in soils. Eur. J. Soil Sci. 1982, 33, 141-163. [CrossRef] 
19. Oades, J.M. Soil organic matter and structural stability: Mechanisms and implications for management. Plant Soil 1984, 76, 319-337. [CrossRef]

20. Onweremadu, E.; Onyia, V.; Anikwe, M. Carbon and nitrogen distribution in water-stable aggregates under two tillage techniques in Fluvisols of Owerri area, southeastern Nigeria. Soil Tillage Res. 2007, 97, 195-206. [CrossRef]

21. Krol, A.; Lipiec, J.; Turski, M.; Kus, J. Effects of organic and conventional management on physical properties of soil aggregates. Int. Agrophysics 2013, 27, 15-21. [CrossRef]

22. Chen, S.; Wang, W.; Xu, W.; Wang, Y.; Wan, H.; Chen, D.; Tang, Z.; Tang, X.; Zhou, G.; Xie, Z.; et al. Plant diversity enhances productivity and soil carbon storage. Proc. Natl. Acad. Sci. USA 2018, 115, 4027-4032. [CrossRef]

23. Yan, J.; Wang, L.; Hu, Y.; Tsang, Y.F.; Zhang, Y.; Wu, J.; Fu, X.; Sun, Y. Plant litter composition selects different soil microbial structures and in turn drives different litter decomposition pattern and soil carbon sequestration capability. Geoderma 2018, 319, 194-203. [CrossRef]

24. Mukumbuta, I.; Shimizu, M.; Hatano, R. Short-term land-use change from grassland to cornfield increases soil organic carbon and reduces total soil respiration. Soil Tillage Res. 2019, 186, 1-10. [CrossRef]

25. Karhu, K.; Wall, A.; Vanhala, P.; Liski, J.; Esala, M.; Regina, K. Effects of afforestation and deforestation on boreal soil carbon stocks-Comparison of measured C stocks with Yasso07 model results. Geoderma 2011, 164, 33-45. [CrossRef]

26. Feng, J.; Xu, X.; Wu, J.; Zhang, Q.; Zhang, D.; Li, Q.; Long, C.; Chen, Q.; Chen, J.; Cheng, X. Inhibited enzyme activities in soil macroaggregates contribute to enhanced soil carbon sequestration under afforestation in central China. Sci. Total. Environ. 2018, 640-641, 653-661. [CrossRef]

27. Miller, G.; Rees, R.; Griffiths, B.; Ball, B.; Cloy, J. The sensitivity of soil organic carbon pools to land management varies depending on former tillage practices. Soil Tillage Res. 2019, 194, 104299. [CrossRef]

28. Liu, M.; Han, G.; Li, Z.; Liu, T.; Yang, X.; Wu, Y.; Song, Z. Effects of slope position and land use on the stability of aggregateassociated organic carbon in calcareous soils. Acta Geochim. 2017, 36, 456-461. [CrossRef]

29. Kadlec, V.; Holubík, O.; Procházková, E.; Urbanová, J.; Tippl, M. Soil organic carbon dynamics and its influence on the soil erodibility factor. Soil Water Res. 2012, 7, 97-108. [CrossRef]

30. Krull, E.S.; Skjemstad, J.O.; Baldock, J.A. Functions of Soil Organic Matter and the Effect on Soil Properties: Cooperative Research Centre for Greenhouse Accounting Canberra, NSW, Australia; Grains Research \& Development Corporation: Canaberra, Australia, 2004.

31. Ndomba, P.M. Modeling of Erosion Processes and Reservoir Sedimentation Upstream of Nyumba ya Mungu Reservoir in the Pangani Basin. Ph.D. Thesis, University of Dar es Salaam, Dar es Salaam, Tanzania, 2007.

32. Kijazi, A.L.; Reason, C.J.C. Analysis of the 2006 floods over northern Tanzania. Int. J. Clim. 2009, 29, 955-970. [CrossRef]

33. Mahongo, S.B.; Shaghude, Y.W. Modelling the dynamics of the Tanzanian coastal waters. J. Oceanogr. Mar. Sci. $2014,5,1-7$.

34. Røhr, P.C.; Killingtveit, A. Rainfall distribution on the slopes of Mt Kilimanjaro. Hydrol. Sci. J. 2003, 48, 65-77. [CrossRef]

35. Hellar-Kihampa, H.; Potgieter-Vermaak, S.; Van Meel, K.; Rotondo, G.G.; Kishimba, M.; Van Grieken, R. Elemental composition of bottom-sediments from Pangani river basin, Tanzania: Lithogenic and anthropogenic sources. Toxicol. Environ. Chem. 2012, 94, 525-544. [CrossRef]

36. Shaghude, Y.W. Review of water resource exploitation and landuse pressure in the Pangani River Basin. West. Indian Ocean J. Mar. Sci. 2007, 5, 195-208. [CrossRef]

37. IUCN/PBWO. Scenario Report: The Analysis of Water Allocation Scenarios for the Pangani River Basin; The World Conservation Union: Gland, Switzerland; Pangani Basin Water Office: Moshi, Tanzania, 2008.

38. Schlüter, T. Geological Atlas of Africa; Springer: Berlin/Heidelberg, Germany, 2008; p. 307.

39. Mzuza, M.K.; Zhang, W.; Kapute, F.; Selemani, J.R. Magnetic properties of sediments from the Pangani River Basin, Tanzania: Influence of lithology and particle size. J. Appl. Geophys. 2017, 143, 42-49. [CrossRef]

40. Dewitte, O.; Jones, A.; Spaargaren, O.; Breuning-Madsen, H.; Brossard, M.; Dampha, A.; Deckers, J.; Gallali, T.; Hallett, S.; Jones, R.; et al. Harmonisation of the soil map of Africa at the continental scale. Geoderma 2013, 211-212, 138-153. [CrossRef]

41. McClaugherty, C. Soils and Decomposition; Mount Union College: Alliance, OH, USA, 2001.

42. Schaetzl, R.J.; Thompson, M.L. Soils; Cambridge University Press: Cambridge, UK, 2015.

43. Turpie, J.; Ngaga, Y.M.; Karanja, F. Catchment Ecosystems and Downstream Water: The Value of Water Resources in the Pangani Basin, Tanzania; Technical Report; IUCN-The World Conservation Union, Ecosystems and Livelihoods Group Asia: Bangkok, Thailand, 2005.

44. Liang, X.; Liu, X.; Li, X.; Chen, Y.; Tian, H.; Yao, Y. Delineating multi-scenario urban growth boundaries with a CA-based FLUS model and morphological method. Landsc. Urban Plan. 2018, 177, 47-63. [CrossRef]

45. Taweesuk, S.; Thammapala, P. Expert classification technique for mapping teak plantation areas in Thailand. In Proceedings of the Pecora 16 "Global Priorities in Land Remote Sensing", Sioux Falls, SD, USA, 23-27 October 2005.

46. Saskia, V.; Henri, H.; Christy, V.B.; Angelique, V.H. Placing soil information in the hands of farmers. Proceedings 2019, $30,88$. [CrossRef]

47. Nelson, D.W.; Sommers, L.E. Total carbon, organic carbon, and organic matter. Soil Sci. Soc. Am. 1996, 5, 961-1010.

48. Pribyl, D.W. A critical review of the conventional SOC to SOM conversion factor. Geoderma 2010, 156, 75-83. [CrossRef]

49. Sprengel, C. About plant humus, humic acid and humic acid salts. Pharm. Arch. 1827, 21, 261-263. [CrossRef]

50. Herrick, J.; Whitford, W.; de Soyza, A.; Van Zee, J.; Havstad, K.; Seybold, C.; Walton, M. Field soil aggregate stability kit for soil quality and rangeland health evaluations. Catena 2001, 44, 27-35. [CrossRef] 
51. Said, M.; Komakech, H.C.; Munishi, L.K.; Muzuka, A.N.N. Evidence of climate change impacts on water, food and energy resources around Kilimanjaro, Tanzania. Reg. Environ. Chang. 2019, 19, 2521-2534. [CrossRef]

52. Hyandye, C.; Martz, L.W. A Markovian and cellular automata land-use change predictive model of the Usangu Catchment. Int. J. Remote. Sens. 2017, 38, 64-81. [CrossRef]

53. Soini, E. Land use change patterns and livelihood dynamics on the slopes of Mt. Kilimanjaro, Tanzania. Agric. Syst. 2005, 85, 306-323. [CrossRef]

54. Hemp, A. Climate change and its impact on the forests of Kilimanjaro. Afr. J. Ecol. 2009, 47, 3-10. [CrossRef]

55. Neff, R.; Chang, H.; Knight, C.G.; Najjar, R.G.; Yarnal, B.; Walker, H.A. Impact of climate variation and change on mid-Atlantic Region hydrology and water resources. Clim. Res. 2000, 14, 207-218. [CrossRef]

56. Blake, W.H.; Rabinovich, A.; Wynants, M.; Kelly, C.; Nasseri, M.; Ngondya, I.; Patrick, A.; Mtei, K.; Munishi, L.; Boeckx, P.; et al. Soil erosion in East Africa: An interdisciplinary approach to realising pastoral land management change. Environ. Res. Lett. 2018, 13, 124014. [CrossRef]

57. McKenzie, J.M.; Mark, B.; Thompson, L.G.; Schotterer, U.; Lin, P.-N. A hydrogeochemical survey of Kilimanjaro (Tanzania): Implications for water sources and ages. Hydrogeol. J. 2010, 18, 985-995. [CrossRef]

58. Thompson, L.G.; Mosley-Thompson, E.; Davis, M.E.; Henderson, K.A.; Brecher, H.H.; Zagorodnov, V.S.; Mashiotta, T.A.; Lin, P.-N.; Mikhalenko, V.N.; Hardy, D.R.; et al. Kilimanjaro ice core records: Evidence of holocene climate change in tropical Africa. Science 2002, 298, 589-593. [CrossRef] [PubMed]

59. Rastner, P.; Prinz, R.; Notarnicola, C.; Nicholson, L.; Sailer, R.; Schwaizer, G.; Paul, F. On the automated mapping of snow cover on glaciers and calculation of snow line altitudes from multi-temporal landsat data. Remote. Sens. 2019, 11, 1410. [CrossRef]

60. Gitec, W. Groundwater Assessment of the Pangani Basin, Tanzania; The Pangani Basin Water Board: Kilimanjaro, Tanzania; International Union for Conservation of Nature: Gland, Switzerland, 2011; Volume 151, pp. 1-156.

61. Mbonile, M.J. Migration and intensification of water conflicts in the Pangani Basin, Tanzania. Habitat Int. 2005, 29 , 41-67. [CrossRef]

62. Yanda, P.; Shishira, E. Water resources management in the Pangani River Basin: Challenges and opportunities. In Forestry Conservation and Resource Utilisation on the Southern Slopes of Mount Kilimanjaro: Trends, Conflicts and Resolutions; Dar es Salaam University Press: Dar es Salaam, Tanzania, 2001; pp. 104-117.

63. Misana, S.B.; Sokoni, C.; Mbonile, M.J. Land-use/cover changes and their drivers on the slopes of Mount Kilimanjaro, Tanzania. J. Geogr. Reg. Plan. 2012, 5, 151-164.

64. Ndomba, P.M. Validation of GLASOD map for sediment sources and erosion processes identification in the Nyumba ya Mungu reservoir catchment. Int. J. Geosci. 2015, 6, 972-986. [CrossRef]

65. Walker, S.M.; Desanker, P.V. The impact of land use on soil carbon in Miombo Woodlands of Malawi. For. Ecol. Manag. 2004, 203, 345-360. [CrossRef]

66. Arnalds, O. Volcanic soils of Iceland. Catena 2004, 56, 3-20. [CrossRef]

67. Dungait, J.A.; Berhe, A.A.; Gregory, A.S.; Hopkins, D.W. Physical Protection and Mean Residence Time of Soil Carbon; CRC Press: Boca Raton, FL, USA, 2019; pp. 171-182.

68. Collier, S.M.; Green, S.M.; Inman, A.; Hopkins, D.W.; Kendall, H.; Jahn, M.M.; Dungait, J.A.J. Effect of farm management on topsoil organic carbon and aggregate stability in water: A case study from Southwest England, UK. Soil Use Manag. 2021, 37, 49-62. [CrossRef]

69. Sartori, F.; Lal, R.; Ebinger, M.H.; Eaton, J.A. Changes in soil carbon and nutrient pools along a chronosequence of poplar plantations in the Columbia Plateau, Oregon, USA. Agric. Ecosyst. Environ. 2007, 122, 325-339. [CrossRef]

70. Six, J.; Bossuyt, H.; Degryze, S.; Denef, K. A history of research on the link between (micro) aggregates, soil biota, and soil organic matter dynamics. Soil Tillage Res. 2004, 79, 7-31. [CrossRef]

71. Emadodin, I.; Reiss, S.; Bork, H.R. A study of the relationship between land management and soil aggregate stability (case study near Albersdorf, Northern-Germany). J. Agric. Biol. Sci. 2009, 4, 48-53.

72. Deng, L.; Shangguan, Z.-P.; Sweeney, S. “Grain for green” driven land use change and carbon sequestration on the Loess Plateau, China. Sci. Rep. 2014, 4, 7039. [CrossRef] [PubMed]

73. Seeger, M.; Rodrigo-Comino, J.; Iserloh, T.; Brings, C.; Ries, J.B. Dynamics of runoff and soil erosion on abandoned steep vineyards in the Mosel Area, Germany. Water 2019, 11, 2596. [CrossRef]

74. Cerdà, A.; Rodrigo-Comino, J.; Novara, A.; Brevik, E.C.; Vaezi, A.R.; Pulido, M.; Giménez-Morera, A.; Keesstra, S. Long-term impact of rainfed agricultural land abandonment on soil erosion in the Western Mediterranean basin. Prog. Phys. Geogr. Earth Environ. 2018, 42, 202-219. [CrossRef]

75. Abrishamkesh, S.; Gorji, M.; Asadi, H.J.I.A. Long-term effects of land use on soil aggregate stability. Int. Agrophysics 2011, 25, 103-108.

76. ̌̌imanský, V.; Juriga, M.; Jonczak, J.; Uzarowicz, Ł.; Stępień, W. How relationships between soil organic matter parameters and soil structure characteristics are affected by the long-term fertilization of a sandy soil. Geoderma 2019, 342, 75-84. [CrossRef]

77. Dai, H.; Chen, Y.; Liu, K.; Li, Z.; Qian, X.; Zang, H.; Yang, X.; Zhao, Y.; Shen, Y.; Li, Z.; et al. Water-stable aggregates and carbon accumulation in barren sandy soil depend on organic amendment method: A three-year field study. J. Clean. Prod. 2019, 212, 393-400. [CrossRef] 
78. Nath, A.J.; Rattan, L.J.P. Effects of tillage practices and land use management on soil aggregates and soil organic carbon in the north Appalachian region, USA. Pedosphere 2017, 27, 172-176. [CrossRef]

79. Delelegn, Y.T.; Purahong, W.; Blazevic, A.; Yitaferu, B.; Wubet, T.; Göransson, H.; Godbold, D.L. Changes in land use alter soil quality and aggregate stability in the highlands of northern Ethiopia. Sci. Rep. 2017, 7, 13602. [CrossRef] [PubMed]

80. Tang, F.K.; Cui, M.; Lu, Q.; Liu, Y.G.; Guo, H.Y.; Zhou, J.X. Effects of vegetation restoration on the aggregate stability and distribution of aggregate-associated organic carbon in a typical karst gorge region. Solid Earth 2016, 7, 141-151. [CrossRef]

81. Watts, C.; Dexter, A. The influence of organic matter in reducing the destabilization of soil by simulated tillage. Soil Tillage Res. 1997, 42, 253-275. [CrossRef]

82. Zhang, B.; Horn, R.; Hallett, P.D. Mechanical resilience of degraded soil amended with organic matter. Soil Sci. Soc. Am. J. 2005, 69, 864-871. [CrossRef]

83. Dungait, J.A.; Cardenas, L.M.; Blackwell, M.; Wu, L.; Withers, P.J.; Chadwick, D.R.; Bol, R.; Murray, P.; Macdonald, A.; Whitmore, A.; et al. Advances in the understanding of nutrient dynamics and management in UK agriculture. Sci. Total. Environ. 2012, 434, 39-50. [CrossRef]

84. Paustian, K.; Collier, S.; Baldock, J.; Burgess, R.; Creque, J.; DeLonge, M.; Dungait, J.; Ellert, B.; Frank, S.; Goddard, T.; et al. Quantifying carbon for agricultural soil management: From the current status toward a global soil information system. Carbon Manag. 2019, 10, 567-587. [CrossRef] 